\title{
Biofilm formation on enteral feeding tubes by Cronobacter sakazakii, Salmonella serovars and other Enterobacteriaceae
}

\author{
E. Hurrell, E. Kucerova, M. Loughlin, J. Caubilla-Barron, S.J. Forsythe * \\ School of Science and Technology, Nottingham Trent University, Clifton Lane, Nottingham, NG11 8NS, UK
}

\section{A R T I C L E I N F O}

Available online $\mathrm{xxxx}$

\section{Keywords:}

Cronobacter

Salmonella

Enterobacteriaceae

Biofilm formation

Enteral feeding tubes

\begin{abstract}
A B S T R A C T
WHO (2007) recommended that to reduce microbial risks, powdered infant formula should be reconstituted with water at temperatures $>70^{\circ} \mathrm{C}$, and that such feeds should be used within $2 \mathrm{~h}$ of preparation. However, this recommendation does not consider the use of enteral feeding tubes which can be in place for more than $48 \mathrm{~h}$ and can be loci for bacterial attachment. This study determined the extent to which 29 strains of Cronobacter sakazakii, Salmonella serovars, other Enterobacteriaceae and Acinetobacter spp. can adhere and grow on enteral feeding tubes composed of polyvinyl chloride and polyurethane. The study also included silver-impregnated tubing which was expected to have antibacterial activity.

Bacterial biofilm formation by members of the Enterobacteriaceae was ca. $10^{5}-10^{6} \mathrm{cfu} / \mathrm{cm}$ after $24 \mathrm{~h}$. Negligible biofilm was detected for Acinetobacter gensp. 13; ca. $10 \mathrm{cfu} / \mathrm{cm}$, whereas Cr. sakazakii strain ATCC 12868 had the highest biofilm cell density of $10^{7} \mathrm{cfu} / \mathrm{cm}$. Biofilm formation did not correlate with capsule production, and was not inhibited on silver-impregnated tubing. Bacteria grew in the tube lumen to cell densities of $10^{7} \mathrm{cfu} / \mathrm{ml}$ within $8 \mathrm{~h}$, and $10^{9} \mathrm{cfu} / \mathrm{ml}$ within $24 \mathrm{~h}$. It is plausible that in vivo the biofilm will both inoculate subsequent routine feeds and as the biofilm ages, clumps of cells will be shed which may survive passage through the neonate's stomach. Therefore biofilm formation on enteral feeding tubes constitutes a risk factor for susceptible neonates.
\end{abstract}

(C) 2009 Elsevier B.V. All rights reserved.

\section{Introduction}

In 2004, following international concern over the microbiological safety of powdered infant formula, the FAO/WHO (2004) undertook a risk assessment of the organisms associated with neonatal infections and powdered infant formula. They categorised Cronobacter spp. (Enterobacter sakazakii) and Salmonella serovars as 'clear evidence of causality' (Category 1), and other Enterobacteriaceae were deemed 'causality plausible, but not yet demonstrated' (Category 2). Acinetobacter spp. was added to the latter group by FAO/WHO in 2006. Members of the Cronobacter genus are associated with infections of immunocompromised individuals especially neonates (Forsythe, 2005; Iversen et al., 2008). Bowen and Braden (2006) considered 46 cases of Cronobacter infections in neonates. They reported that the symptoms of very low birth weight neonates (age of onset $\mathrm{ca}$. 1 month) tend to be bacteraemia, whereas those of birth weight $c a .2000 \mathrm{~g}$ suffered from meningitis and an onset age of a few days. Due to the association of some Cronobacter cases with contaminated powdered infant formula, this product has come under considerable attention with regard to its microbial safety and various detection methods have been developed (Fanning and Forsythe, 2008). It

\footnotetext{
* Corresponding author. School of Science and Technology, Clifton Lane, Nottingham, NG11 8NS, UK. Tel.: +44 115 8483529; fax: +44 1158486636.

E-mail address: stephen.forsythe@ntu.ac.uk (S.J. Forsythe).

URL: http://www.foodmicrobe.com (S.J. Forsythe).
}

is expected that intrinsic contamination of powdered infant formula will decrease due to the subsequent improved industrial processes and microbiological criteria (Codex Alimentarius Commission, 2008a,b). However, despite the long established methods for the detection of Salmonella serovars, along with monitoring and control measures, between 1985 and 2005 there were at least 6 outbreaks of salmonellosis associated with infant formula (Cahill et al., 2008). These cases involved ca. 287 infants in total. More recently, there have been two further outbreaks of Salmonella associated with infant formula in France and Spain involving 14 and 23 cases (Jourdan et al., 2008; Soler et al., 2008). Therefore routes of neonatal infection via infant formula need to be reconsidered in order to implement any necessary additional control measures.

The FAO/WHO meetings in 2004 and 2006 stressed that multiplication of Cronobacter spp., Salmonella serovars, and Category 2 organisms following reconstitution equated to increased risk of infection. Subsequently the WHO (2007) recommended that to reduce microbial risks, powdered infant formula should be reconstituted with water at temperatures $>70^{\circ} \mathrm{C}$, and that such feeds should be used within $2 \mathrm{~h}$ of preparation. Three reported outbreaks of Cronobacter spp. have involved possible temperature abuse of reconstituted feed, allowing bacterial overgrowth to occur (Himelright et al., 2002; Van Acker et al., 2001; Caubilla-Barron et al., 2007). Nevertheless, the WHO recommendation does not consider the use of enteral feeding tubes which can be in place for more than $48 \mathrm{~h}$ and can be loci for bacterial attachment (Mehall et al., 2002). Since the tubes 
are at body temperature and contain nutrients (infant formula), it is reasonable to anticipate that bacteria will multiply in the tube and contaminate subsequent feeds. It is already known that Cronobacter spp. can form biofilms on plastic surfaces (Iversen et al. 2004; Kim et al. 2006).

Kim et al. (2006) reported that Cronobacter spp. attached to enteral feeding tubes at ambient temperatures, and as the biofilm aged the cells became detached. The detached cells will be in clumps, and may be protected from the stomach acidity due to capsule formation. Consequently they may pass into the infant intestines and constitute a risk to neonatal health. The attachment of Acinetobacter spp., and Enterobacteriaceae, including Cronobacter spp. and Salmonella serovars, to enteral feeding tubes at body temperature (as occurs with enteral feeding of neonates on an intensive care unit) has not been considered in detail previously. This study has determined the attachment of Enterobacteriaceae and Acinetobacter, organisms associated with neonatal infections, to enteral feeding tubes. The study included silver-impregnated tubing which is expected to have antibacterial activity.

\section{Materials and methods}

\subsection{Bacterial strains}

Bacterial species included 29 strains of $\mathrm{Cr}$. sakazakii, Salmonella serovars, Enterobacter cloacae, Citrobacter freundii, Cit. koseri, Pantoea spp., Escherichia coli, Esch. hermanii, Esch. vulneris, Klebsiella oxytoca, K. pneumoniae, Hafnia alvei, Serratia marcescens, and Acinetobacter species. The bacterial strains and their sources are summarised in Table 1 . Where possible strains were chosen on the basis of isolation source (powdered infant formula, dairy products, or enteral feeding tubes). Additionally, in order to investigate any correlation between capsule production and biofilm formation, Cr. sakazakii strains were chosen according to the amount of capsule production on milk agar; Table 2.

Table 1

Description of strains used in this study.

\begin{tabular}{ll}
\hline Organism & Source \\
\hline Cr. sakazakii NCTC $11467^{\text {T }}$ & Infant clinical \\
Cr. sakazakii ATCC 12868 & Unknown \\
Cr. sakazakii 1 & Powdered infant formula \\
Cr. sakazakii 2 & Powdered infant formula \\
Cr. sakazakii 3 & Powdered infant formula \\
Cr. sakazakii 4 & Enteral feeding tube \\
Cr. sakazakii 5 & Powdered infant formula \\
Cr. sakazakii 6 & Powdered infant formula \\
Cr. sakazakii 7 & Powdered infant formula \\
Cr. sakazakii 8 & Raw material \\
Cr. sakazakii 9 & Unknown \\
Cr. sakazakii 10 & Environmental \\
Sal. enterica serovar Anatum & Dairy product \\
Sal. Give & Dairy product \\
Sal. Kedougou & Clinical isolate \\
Esch. coli K12 & Unknown \\
Esch. hermanii & Milk powder \\
Esch. vulneris & Powdered infant formula \\
Cit. freundii & Powdered infant formula \\
Cit. koseri & Powdered infant formula \\
Ent. cloacae & Powdered infant formula \\
Ent. hormaechei & Enteral feeding tube \\
Hafnia alvei & Dairy unit \\
Klebsiella oxytoca & ATCC 41365 \\
K. pneumoniae & Milk powder \\
Pantoea spp. & Powdered infant formula \\
Ser. marcescens & Enteral feeding tube \\
Acinetobacter gensp. 13 & Cheese \\
A. calcoaceticus & Cheese \\
\hline & \\
\hline
\end{tabular}

\subsection{Tubing}

Three types of tubing were evaluated for supporting bacterial biofilm formation; polyvinylchloride (PVC, gauge 3.5), polyurethane (PU, gauge 5), and silver-impregnated flexilene plastic. The first 2 types of tubing are used as enteral feeding tubes. The silverimpregnated tubing is not used as enteral feeding tube, but was evaluated for its potential antibacterial activity.

\subsection{Bacterial capsule formation determination}

Bacterial capsule production on milk agar was determined as previously described (Caubilla-Barron and Forsythe, 2007). Three grams of agar (LP0011, Oxoid Ltd., Basingstoke, UK) and $0.4 \mathrm{~g}$ of ammonium sulphate were dissolved in $40 \mathrm{ml}$ of distilled water. After autoclaving $\left(121^{\circ} \mathrm{C}\right.$ for $15 \mathrm{~min}$ ) the mixture was combined with $200 \mathrm{ml}$ of warm $\left(55^{\circ} \mathrm{C}\right)$ sterile whey-based ready to feed infant formula milk and dispensed into Petri dishes. Plates were inoculated and incubated for $24 \mathrm{~h}$, at $37^{\circ} \mathrm{C}$. Colony morphology was compared with $\mathrm{Cr}$. sakazakii strains NCTC $11467^{\mathrm{T}}$ (non-capsulated) and ATCC 12868 (capsulated) as previously described by Iversen et al. (2004).

\subsection{Biofilm formation determination}

Biofilm formation was determined using the impedance technique (Silley \& Forsythe, 1996) with the Rapid Automated Bacterial Impedance Technique (RABITтM, Don Whitley Scientific Ltd., UK). Bacterial inocula were grown at $37{ }^{\circ} \mathrm{C}$ overnight without shaking in sterile infant formula. Ten millilitre volumes of sterile infant formula containing five $1 \mathrm{~cm}$ lengths of tubing (sterilised by immersion in 70\% ethanol) were inoculated with $0.1 \mathrm{ml}$ of an overnight culture. After incubation for $24 \mathrm{~h}$ at $37^{\circ} \mathrm{C}$ without shaking, the infant formula was aseptically removed and an aliquot retained for viable count determination on TSA (Merck 1.05458). The five $1 \mathrm{~cm}$ pieces of tubing were washed by aseptically transferring to $10 \mathrm{ml}$ of sterile saline followed by shaking for $2 \mathrm{~min}$. This procedure was repeated a further two times. Each piece of tubing with remaining bacterial biofilm was transferred to a sterile impedance tube containing $2 \mathrm{ml}$ of Brain Heart Infusion broth (BHI, Merck 1.10493), and placed in the impedance instrument (RABITTM) within $10 \mathrm{~min}$ of preparation. Therefore, there were five replicates for each bacteria-tubing combination. The impedance calibration curves for each bacterial strain were established using plate counts on TSA at $37{ }^{\circ} \mathrm{C}$ for $24 \mathrm{~h}$. Bacterial biofilm values were expressed as viable count $\left(\log _{10} \mathrm{cfu}\right) \mathrm{cm}^{-1}$ of tubing.

\subsection{Growth rate determination}

To determine the growth rate of the organisms, $0.1 \mathrm{ml}$ decimal dilutions of overnight cultures were inoculated into $2 \mathrm{ml}$ infant formula (whey-based) and incubated at $37^{\circ} \mathrm{C}$. The doubling time was calculated from the growth response calibration curve as previously described (Silley \& Forsythe 1996; Iversen et al. 2004).

\subsection{Bacterial attachment to enteral feeding tube wall and inoculation of lumen contents}

To mimic hospital practices with respect to frequency of feeding, enteral feeding tubes were inoculated with $C r$. sakazakii strains ATCC 12868 and 4 followed by flushing at regular intervals with sterile infant formula. The bacterial strains were grown beforehand at $37^{\circ} \mathrm{C}$ in liquid infant formula for $18 \mathrm{~h}$, and then diluted to $10^{5} \mathrm{cfu} / \mathrm{ml}$ in sterile saline. The culture was syringed through PVC enteral feeding tubes, which were then incubated at $37^{\circ} \mathrm{C}$. At 2 hourly intervals, the residual lumen liquid was displaced into a sterile Eppendorf tube by attaching a sterile syringe to the tube and pushing air through the tubing. Afterwards, $10 \mathrm{ml}$ sterile liquid formula was syringed through 
Table 2

Capsule production and biofilm formation of Enterobacteriaceae and Acinetobacter spp. on enteral feeding tubes, and silver-impregnated tubing.

\begin{tabular}{|c|c|c|c|c|c|c|c|c|c|c|}
\hline \multirow[t]{2}{*}{ Organism } & \multirow[t]{2}{*}{ Capsule production } & \multicolumn{3}{|c|}{$\begin{array}{l}\text { Polyvinylchloride } \\
\left(\log _{10} \mathrm{cfu} / \mathrm{cm}\right)\end{array}$} & \multicolumn{3}{|c|}{$\begin{array}{l}\text { Polyurethane } \\
\left(\log _{10} \mathrm{cfu} / \mathrm{cm}\right)\end{array}$} & \multicolumn{3}{|c|}{$\begin{array}{l}\text { Silver-impregnated } \\
\left(\log _{10} \mathrm{cfu} / \mathrm{cm}\right)\end{array}$} \\
\hline & & Av & $\operatorname{Max}$ & Min & $\mathrm{Av}$ & Max & Min & Av & Max & Min \\
\hline Cr. sakazakii NCTC $11467^{\mathrm{T}}$ & - & 5.7 & 6.3 & 4.0 & 6.2 & 6.6 & 5.2 & 6.3 & 6.8 & 5.1 \\
\hline Cr. sakazakii ATCC 12868 & +++ & 4.6 & 4.8 & 4.3 & 6.3 & 6.7 & 5.6 & 6.4 & 6.5 & 6.1 \\
\hline Cr. sakazakii 1 & +++ & 6.3 & 6.4 & 5.8 & 5.6 & 5.9 & 5.3 & 7.4 & 7.7 & 7.0 \\
\hline Cr. sakazakii 2 & +++ & 5.5 & 5.7 & 4.9 & 5.9 & 6.1 & 5.5 & 7.0 & 7.0 & 6.5 \\
\hline Cr. sakazakii 3 & +++ & 5.3 & 5.6 & 5.0 & 6.2 & 6.7 & 5.8 & 6.5 & 6.8 & 6.1 \\
\hline Cr. sakazakii 4 & +++ & 5.0 & 5.4 & 4.5 & 6.7 & 6.7 & 6.7 & 6.1 & 6.3 & 5.1 \\
\hline Cr. sakazakii 5 & ++ & 5.6 & 5.8 & 5.3 & 5.5 & 5.6 & 5.1 & 5.3 & 5.4 & 5.1 \\
\hline Cr. sakazakii 6 & ++ & 4.6 & 4.9 & 4.0 & 5.3 & 5.5 & 4.7 & 6.0 & 6.4 & 5.0 \\
\hline Cr. sakazakii 7 & + & 5.9 & 6.2 & 5.2 & 6.4 & 6.9 & 5.7 & 6.4 & 6.9 & 5.7 \\
\hline Cr. sakazakii 8 & + & 4.6 & 4.9 & 4.5 & 5.3 & 5.5 & 5.0 & 5.4 & 5.6 & 5.1 \\
\hline Cr. sakazakii 9 & - & 5.3 & 5.5 & 4.4 & 5.9 & 6.1 & 5.7 & 6.1 & 6.5 & 4.6 \\
\hline Cr. sakazakii 10 & - & 6.2 & 6.6 & 5.5 & 6.9 & 7.0 & 6.6 & 6.9 & 7.2 & 6.5 \\
\hline Sal. Anatum & + & 6.6 & 6.9 & 5.3 & 6.6 & 6.8 & 6.3 & 6.7 & 7.1 & 5.9 \\
\hline Sal. Give & + & 5.3 & 5.7 & 5.0 & 6.9 & 7.3 & 6.3 & 6.7 & 7.0 & 6.3 \\
\hline Sal. Kedougou & ++ & 5.7 & 5.9 & 5.2 & 6.0 & 6.2 & 5.5 & 5.6 & 5.7 & 5.2 \\
\hline Esch. coli K12 & - & 4.4 & 4.7 & 3.9 & 4.6 & 4.6 & 4.6 & 4.4 & 4.5 & 4.2 \\
\hline Esch. hermanii & - & 6.3 & 6.6 & 6.1 & 6.7 & 6.8 & 6.6 & 6.7 & 6.9 & 6.1 \\
\hline Esch. vulneris & - & 6.4 & 6.6 & 5.9 & 6.4 & 6.8 & 5.8 & 6.5 & 6.9 & 6.0 \\
\hline Cit. freundii & - & 5.1 & 5.4 & 4.4 & 5.9 & 6.1 & 5.5 & 5.9 & 6.3 & 5.4 \\
\hline Cit. koseri & - & 5.1 & 5.3 & 4.8 & 6.0 & 6.2 & 5.8 & 6.0 & 6.1 & 5.7 \\
\hline Ent. cloacae & ++ & 5.1 & 5.5 & 3.4 & 5.9 & 6.0 & 5.6 & 3.7 & 3.9 & 3.3 \\
\hline Ent. hormaechei & + & 5.7 & 6.0 & 4.9 & 6.4 & 6.7 & 5.9 & 5.6 & 5.7 & 5.5 \\
\hline H. alvei & - & 4.9 & 5.0 & 4.7 & 5.1 & 5.2 & 4.8 & 5.6 & 5.8 & 5.0 \\
\hline K. oxytoca & - & 5.2 & 5.5 & 4.7 & 5.4 & 5.8 & 4.9 & 6.0 & 6.5 & 5.4 \\
\hline K. pneumoniae & + & 5.6 & 5.7 & 5.2 & 5.2 & 5.4 & 5.0 & 5.9 & 6.2 & 5.7 \\
\hline Pantoea spp. & ++ & 5.6 & 5.9 & 5.2 & 5.6 & 5.6 & 5.4 & 6.2 & 6.3 & 6.2 \\
\hline Ser. marcenscens & + & 5.8 & 4.1 & 6.2 & 5.9 & 4.0 & 6.4 & 6.2 & 6.4 & 5.4 \\
\hline Acinetobacter gensp.13 & - & 4.1 & 4.0 & 4.1 & 2.9 & 3.3 & 1.6 & 4.8 & 5.3 & 4.1 \\
\hline A. calcoaceticus & + & 1.3 & 1.7 & 0.7 & 0.5 & 1.0 & -2.0 & 0.6 & 1.0 & 0.1 \\
\hline
\end{tabular}

the tubing which was then reincubated at $37^{\circ} \mathrm{C}$. The number of bacteria in the lumen liquid, and attached to the tube wall was enumerated as described above.

\subsection{Scanning electron microscopy of $\mathrm{Cr}$. sakazakii attachment to enteral feeding tube}

PVC tubing which had been incubated with $C r$. sakazakii strain ATCC 12868 overnight, as described above, was fixed using 3\% gluteraldehyde prepared in a $0.1 \mathrm{M}$ phosphate buffer. The tubing was cut into representative $1 \mathrm{~cm}$ lengths and dissected longitudinally to expose the inner surface. The pieces were then washed in $0.1 \mathrm{M}$ phosphate buffer, post fixed in $1 \%(\mathrm{w} / \mathrm{v}$ ) osmium tetroxide, dehydrated through a gradual series of alcohols up to $100 \%$ alcohol and then treated with hexamethyldisilazane $(100 \%)$ for 5 min. The airdried pieces were then attached to aluminium stubs, sputter-coated with gold and examined using a Stereoscan S250 Mark III SEM at 10$20 \mathrm{KV}$.

\section{Results}

Capsule formation by 29 strains of various Enterobacteriaceae genera and Acinetobacter spp. was determined by colony appearance on milk agar; Table 2. Cr. sakazakii strains ATCC 12868, 1, 2, 3 and 4 had the most mucoid appearance indicating capsular material production. Strains 1-3 had been isolated from powdered infant formula (Table 1), and strain 4 from an enteral feeding tube on a neonatal intensive care unit. Less capsular material was produced by the $\mathrm{Cr}$. sakazakii strains 5-8. The dry colony appearance of the $\mathrm{Cr}$. sakazakii type strain NCTC $11467^{\mathrm{T}}, 9$ and 10 indicated no capsular material was produced. Cr. sakazakii NCTC $11467^{\mathrm{T}}$ was a clinical isolate from a child's throat, and the remaining two were from powdered infant formula. Sal. Kedougou, Ent. cloacae and Pantoea spp. produced mucoid colonies on milk agar. Whereas, the Salmonella serovars
Anatum and Give, K. pneumoniae and A. calcoaceticus colonies only had a slight mucoid appearance. The cells densities of overnight cultures in infant formula ranged from $10^{8}$ to $10^{10} \mathrm{cfu} / \mathrm{ml}$. Cr. sakazakii and Salmonella serovars, most other Enterobacteriaceae and Acinetobacter spp. had doubling times of 22-27 min. The slowest growing organism was $H$. alvei with a doubling time of $38 \mathrm{~min}$.

Each biofilm cell density measurement was obtained using five replicates. As previously reported (Iversen et al.2004), the biofilm cell density value varied notably between replicates, and hence minimum and maximum values are indicated in Table 2. The 12 strains of $\mathrm{Cr}$. sakazakii grew as biofilms on the three types of tubing; PVC, PU, and silver-impregnated flexelene. The highest biofilm level was recorded with $\mathrm{Cr}$. sakazakii strain 1 on the flexelene tubing at $7.7 \log _{10} \mathrm{cfu} / \mathrm{cm}$. There was no correlation between biofilm cell density, and capsule formation on milk agar; Table 2. Non-mucoidal $C r$. sakazakii strains 9 and 10 produced biofilms at levels which were indistinguishable for the other Cr. sakazakii strains. Sal. Anatum, Sal. Give and Sal. Kedougou produced biofilms on the three types of tubing at levels similar to $\mathrm{Cr}$. sakazakii; $\mathrm{ca} \cdot 10^{5}-10^{7} \mathrm{cfu} / \mathrm{cm}$.

of the remaining Enterobacteriaceae, Esch. coli $\mathrm{K} 12$ had the lowest level $\left(10^{4} \mathrm{cfu} / \mathrm{cm}\right)$ of biofilm formation on all three types of tubing. Esch. hermanii and Esch. vulneris, which also showed no capsule production on milk agar plates, had biofilm levels approximately 100 fold higher at $10^{6} \mathrm{cfu} / \mathrm{cm}$. In general, across all the bacterial species, the level of biofilm formation on the silver-impregnated tubing was higher than that on the PVC and PU enteral feeding tubes. There was no indication of antibacterial activity by the silver-impregnated flexelene tubing, except against Ent. cloacae which showed lower biofilm formation on the silver-impregnated tubing. Biofilm formation by Acinetobacter gensp. 13 was low, and was negligible for $A$. calcoaceticus; Table 2.

Two strains of $\mathrm{Cr}$. sakazakii (ATCC 12868 and 4) were chosen to study the time course of bacterial attachment to PVC tubing. The former is a well studied capsule-producing strain and the latter was 
originally isolated from an enteral feeding tube on a neonatal intensive care unit. PVC tubing was in use at the neonatal intensive care unit from which $\mathrm{Cr}$. sakazakii strain 4 had been isolated. To simulate hospital practices, $37{ }^{\circ} \mathrm{C}$ incubated PVC enteral feeding tubes were gently flushed with fresh sterile formula every $2 \mathrm{~h}$, and the lumen contents collected. The number of bacteria on the tube wall and the residual liquid in the tube lumen was determined using the impedance method. Fig. 1 shows bacterial numbers on the tubing wall was $10^{4}-10^{5} \mathrm{cfu} / \mathrm{cm}$ by $8 \mathrm{~h}$, and $10^{4}-10^{6} \mathrm{cfu} / \mathrm{cm}$ after $24 \mathrm{~h}$. $\mathrm{Cr}$. sakazakii strain 4 produced higher biofilm cell density than strain ATCC 12868. The organisms also multiplied in the fresh liquid feed of the tube lumen to $10^{7} \mathrm{cfu} / \mathrm{ml}$ by $8 \mathrm{~h}, 10^{8}-10^{9} \mathrm{cfu} / \mathrm{ml}$ with $24 \mathrm{~h}$ and had a doubling time of $22 \mathrm{~min}$. Fig. 2 is a scanning electron microscope image of $\mathrm{Cr}$. sakazakii ATCC 12868 biofilm on PVC neonatal enteral feeding tubing after $24 \mathrm{~h}$ incubation. Cells of $\mathrm{Cr}$. sakazakii in clusters can be seen within a matrix of liquid feed material.

\section{Discussion}

Enterobacteriaceae are able to attach to inert surfaces and grow, resulting in biofilm formation (Murga et al. 2001; Thompson et al. 2006; Zogaj et al. 2003). Therefore, it is plausible that bacteria attach in vivo to neonatal enteral feeding tubes, and grow to high cell densities. Cr. sakazakii strain 4, Ent. hormaechei and Ser. marcescens used in this study were originally isolated from discarded enteral feeding tubes in a neonatal intensive care unit and therefore emphasize the clinical significance of this work (Table 1). Enteral feeding tubes are used to feed low birth weight infants on neonatal intensive care units, and may be left in situ for several days. The tubes will be at $37^{\circ} \mathrm{C}$, and receive fresh nutrients (infant feed) at every $2-$ $3 \mathrm{~h}$ according to the neonate's feeding regime (Hurrell et al., in press). As shown in this study Enterobacteriaceae, such as Cr. sakazakii and Salmonella serovars, are able to colonize enteral feeding tubes to high cell densities ( $\mathrm{ca} .10^{5}-10^{6} \mathrm{cfu} / \mathrm{cm}$ ) which will lead to contamination of subsequent feeds (Table 2 and Fig. 1).

Previously, Iversen et al. (2004) reported ca. 2 log variations in the viable counts between replicates of $\mathrm{Cr}$. sakazakii biofilms on polycarbonate, latex and silicon surfaces using the same impedance technique. This large variation was also seen in our study of a wider

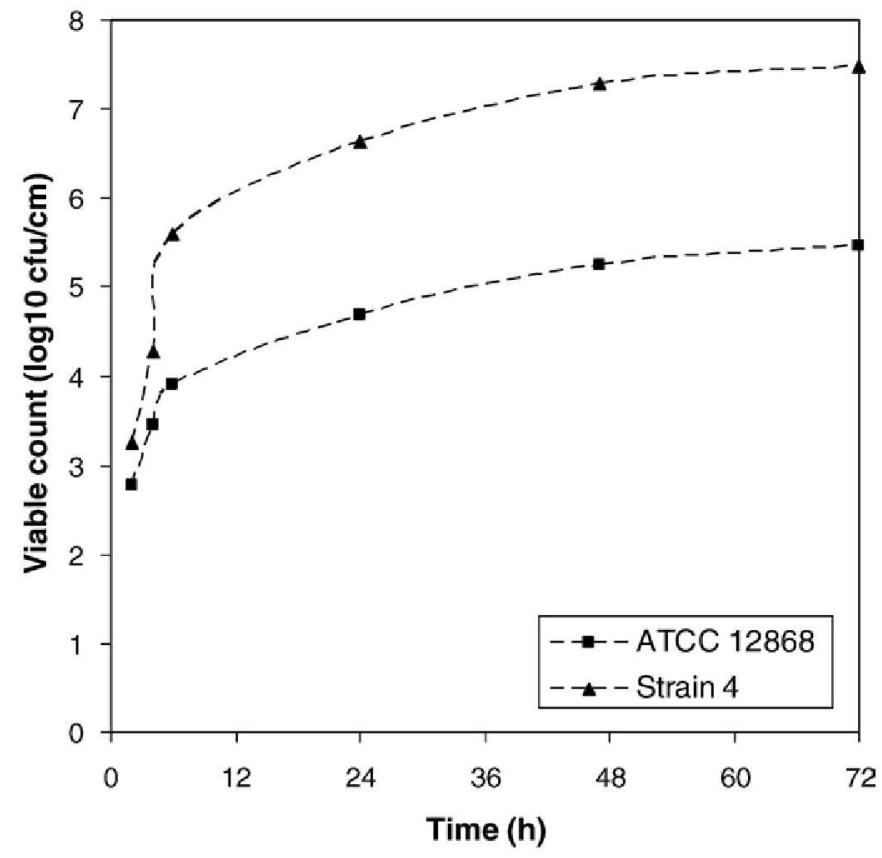

Fig. 1. Cr. sakazakii biofilm formation on enteral feeding tubes.

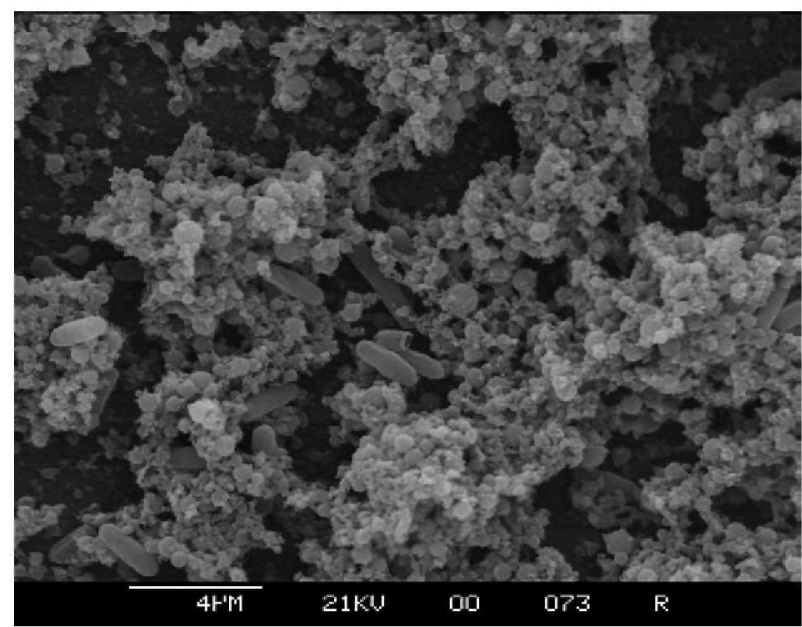

Fig. 2. Electron micrograph of $\mathrm{Cr}$. sakazakii ATCC 12868 attached to PVC enteral feeding tube. Tubes had been incubated with inoculated infant formula for $24 \mathrm{~h}$ before preparation. Cr. sakazakii cells can be seen within the matrix of the infant formula material.

range of Enterobacteriaceae and Acinetobacter spp. and therefore the average, minimum and maximum biofilm cell densities per organism are presented in Table 2 . This variation is probably due to irregular attachment and growth on the tubing and the fragile nature of the biofilm which can be disrupted on washing and transferring to the impedance tubes. This serves to emphasize that a bacterial biofilm on a neonatal enteral feeding tube is unstable and will release clumps of bacteria.

There was no correlation between biofilm cell density, and capsule formation on milk agar for the 29 strains studied; Table 2. For example, Cr. sakazakii strains NCTC $11467^{\mathrm{T}}$ and 10 did not produce any capsule on milk agar plates, yet produced more biofilm on PVC than Cr. sakazakii strains ATCC 12886, 4, and 6. Similarly on PU and silver-impregnated tubing, Cr. sakazakii NCTC $11467^{\mathrm{T}}$ and strain 10 produced more biofilm than most capsulated $\mathrm{Cr}$. sakazakii strains. The biofilm cell densities for other Enterobacteriaceae also varied considerably. Esch. coli K12 and Ent. cloacae formed lower biofilm cell densities than other Enterobacteriaceae, and $A$. calcoaceticus produced negligible biofilm; $\mathrm{ca} .10 \mathrm{cfu} / \mathrm{cm}$. The reason for the variation is unknown, but may be linked to cell surface hydrophobicity as well as surface structure. Other attachment factors warrant further investigation such as curli fimbriae and cellulose production. These have been reported in Cronobacter spp. Enterobacter spp., Citrobacter spp. and Klebsiella spp. (Lehner et al. 2005; Zogaj et al. 2003).

Apart from Ent. cloacae, the bacterial biofilms which formed on silver-impregnated tubing were not significantly less than on PVC and PU tubing. The reason for the susceptibility of Ent. cloacae compared with other Enterobacteriaceae to silver ions is unknown. Nevertheless, overall the results demonstrate a lack of antibacterial activity by the silver ions when impregnated in the plastic. This could have been due to the presence of a conditioning film of formula components acting as a barrier to the diffusion of the silver ions. Consequently, silverimpregnated tubing does not appear to be a means of preventing bacterial biofilm formation on enteral feeding tubes.

Laboratory studies demonstrated the attachment of Cr. sakazakii to enteral feeding tubes within $2 \mathrm{~h}$ of exposure (Fig. 2). In these experiments, the tubes were flushed every $2 \mathrm{~h}$ to mimic hospital practices. The biofilm subsequently inoculated the fresh infant formula in the lumen of the tube and the bacteria grew to $\sim 10^{8} \mathrm{cfu} /$ $\mathrm{ml}$. If this occurs in vivo then the lumen bacteria will be flushed into the neonate's stomach with each subsequent feed. Electron microscopy of enteral tubes incubated with Cr. sakazakii ATCC 12868 showed clumps of cells on the surface and within precipitated feed matrix (Fig. 2). 
This study demonstrates that Enterobacteriaceae and Acinetobacter gensp. 13 are able to attach and grow on enteral feeding tubes as bacterial biofilms. It is plausible that this biofilm will both inoculate subsequent routine feeds and as the biofilm ages, clumps of cells will be shed which may survive passage through the neonate's stomach due to protection from the acidity. Since low birth weight neonates have a low immune status and lack a competing intestinal bacterial flora, these biofilm-associated organisms could result in neonatal infections (Townsend \& Forsythe, 2008). Therefore bacterial growth on enteral feeding tubes will constitute a risk factor to neonatal health. This issue warrants further investigation to reduce neonatal exposure to opportunistic pathogens, in particular susceptible neonates receiving enteral feeding due to possible bacterial growth in situ.

\section{Acknowledgements}

The authors are grateful for the financial support of Mead Johnson Nutrition Co. and Nottingham Trent University, and to Dr W. Cooley (Veterinary Laboratory Agency, Surrey) for the electron microscopy.

\section{References}

Bowen, A.B., Braden, C.R., 2006. Invasive Enterobacter sakazakii disease in infants. Emerging Infectious Disease http://www.cdc.gov/ncidod/EID/vol12no08/05-1509.htm.

Cahill, S.M., Wachsmuth, I.K., de Lourdes Costarrica, M., Ben Embarek, P., 2008. Powdered infant formula as a source of Salmonella infection in infants. Clincial Infectious Disease 46, 268-273.

Caubilla-Barron, J., Forsythe, S., 2007. Dry stress and survival time of Enterobacter sakazakii and other Enterobacteriaceae. Journal of Food Protection 70, 2111-2117.

Caubilla-Barron, J., Hurrell, E., Townsend, S., Cheetham, P., Loc-Carrillo, C., Fayet, O., Prere, M.-F., Forsythe, S.J., 2007. Genotypic and phenotypic analysis of Enterobacter sakazakii strains from an outbreak resulting in fatalities in a neonatal intensive care unit in France. Journal of Clinical Microbiology 45, 3979-3985.

Codex Alimentarius Commission., 2008a. Report of the Thirty-first Session of the Codex Alimentarius Commission. Geneva, Switzerland, 30 June -4 July. Alinorm 08/31 REP. Available at: ftp://ftp.fao.org/codex/Alinorm08/al31REP_adv.pdf.

Codex Alimentarius Commission., 2008b. Code of Hygienic Practice for Powdered Formulae for Infants and Young Children. CAC/RCP 66-2008. http://www codexalimentarius.net/download/standards/11026/cxp 066 ${ }^{\mathrm{e}}$.pdf.

Fanning, S., Forsythe, S.J., 2008. Isolation and identification of E. sakazakii. In: Farber, J., Forsythe, S.J. (Eds.), Enterobacter sakazakii. ASM Press, Washington, DC, pp. 27-59.

Food and Agriculture Organization/World Health Organization (FAO/WHO, 2004. Enterobacter sakazakii and other microorganisms in powdered infant formula. Meeting report, MRA series 6. World Health Organization, Geneva, Switizerland. http://www.who.int/foodsafety/publications/micro/mra6/en/index.html.

Food and Agriculture Organization/World Health Organization (FAO/WHO), 2006. En terobacter sakazakii and Salmonella in powdered infant formula. Second Risk Assessment Workshop. Meeting report, MRA series 10. World Health Organization, Geneva, Switzerland. http://www.who.int/foodsafety/publications/micro/mra10/ en/index.html.
Forsythe, S., 2005. Enterobacter sakazakii and other bacteria in powdered infant milk formula. Maternal and Child Nutrition 1, 51-58.

Himelright, I., Harris, E., Lorch, V., Anderson, M., 2002. Enterobacter sakazakii infections associated with the use of powdered infant formula - Tennessee, 2001. JAMA 287. 2204-2205.

Hurrell, E., Kucerova, E., Loughlin, M., Caubilla-Barron, J., Hilton, A., Armstrong, R., Smith, C., Grant, J., Shoo, S., Forsythe, S., in press. Neonatal enteral feeding tubes as loci for colonisation by members of the Enterobacteriaceae. BMC Infectious Diseases.

Iversen, C., Lane, M., Forsythe, S.J., 2004. The growth profile, thermotolerance and biofilm formation of Enterobacter sakazakii grown in infant formula milk. Letters in Applied Microbiology 38, 378-382.

Iversen, C., Mullane, N., McCardell, B.D., et al., 2008. Cronobacter gen. nov., a new genus to accomodate the biogroups of Enterobacter sakazakii, and proposal of Cronobacter sakazakii gen. nov., comb. nov., Cronobacter malonaticus sp. nov., Cronobacter dublinensis sp. nov., Cronobacter genomospecies 1., and of three subspecies, Cronobacter dublinensis subsp. dublinensis subsp. nov., Cronobacter dublinensis subsp. lausannensis subsp. nov. and Cronobacter dublinenesis subsp. lactaridi subsp. nov. International Journal of Systematic Evolution and Microbiology 58, 1442-1447.

Jourdan, N., Le Hello, S., Delmas, G., Clouzeau, J., Manteau, C., Désaubliaux, B., Chagnon, V., Thierry-Bled, F., Demare, N., Weill, FX., de Valk, H., 2008. Nationwide outbreak of Salmonella enterica serotype Give infections in infants in France, linked to infant milk formula, September 2008. Eurosurveillance 13(39): pii =18994. Available online: http://www.eurosurveillance.org/ViewArticle.aspx?ArticleId=18994.

Kim, H., Ryu, J.-H., Beuchat, L.R., 2006. Attachment and biofilm formation by Enterobacter sakazakii on stainless steel and enteral feeding tubes. Applied Environmental Microbiology 73, 5846-5856.

Lehner, A., Riedel, K., Eberl, L., Breeuwer, P., Diep, B., Stephan, R., 2005. Biofilm formation, extracellular polysaccharide production, and cell-to-cell signaling in various Enterobacter sakazakii strains: aspects promoting environmental persistence. Journal of Food Protection 68, 2287-2294.

Mehall, J.R., Kite, C.A., Saltzman, D.A., Wallett, T., Jackson, R.J., Smith, S.D., 2002. Prospective study of the incidence and complications of bacterial contamination of enteral feeding in neonates. Journal of Pediatric Surgery 37, 1177-1182.

Murga, R., Miller, J.M., Donlan, R.M., 2001. Biofilm formation by Gram-negative bacteria on central venous catheter connectors: effect of conditioning films in a laboratory model. Journal of Clinical Microbiology 39, 2294-2297.

Silley, P., Forsythe, S.J., 1996. Impedance microbiology - a rapid change for microbiologists. Journal of Applied Bacteriology 80, 233-243.

Soler, P. Herrera, S. Rodriguez, J. Cascante, J., Cabral, R. Echerita- Sarriandia, A Mateo, S. 2008. Nationwide outbreak of Salmonella enterica serotype Kedougou infection in infants linked to infant formula milk, Spain, 2008. Eurosurveillance 13(35):p11=18963. Available online: http://www.eurosurveillance.org/ViewArticle.aspx?ArticleId $=18963$.

Thompson, L.J., Gray, V., Lindsay, D., von Holy, A., 2006. Carbon: nitrogen: phosphorus ratios influence biofilm formation by Enterobacter cloacae and Citrobacter freundii. Journal of Applied Microbiology 101, 1105-1113.

Townsend, S., Forsythe, S.J., 2008. The neonatal intestinal microbial flora, immunity, and infections. Chapter 3. In: Farber, J.M., Forsythe, S.]. (Eds.), Enterobacter sakazakii. ASM Press, Washington.

van Acker, J., de Smet, F., Muyldermans, G., Bougatef, A., Naessens, A., Lauwers, S., 2001. Outbreak of necrotizing enterocolitis associated with Enterobacter sakazakii in powdered milk formula. Journal of Clinical Microbiology 39, 293-297.

WHO., 2007. Safe preparation, storage and handling of powdered infant formula guidelines. http:/ www.who.int/foodsafety/publications/micro/pif2007/en/index.html.

Zogaj, X., Bokranz, W., Nimtz, M., Römling, U., 2003. Production of cellulose and curli fimbriae by members of the Family Enterobacteriaceae isolated from the human gastrointestinal tract. Infection and Immunity 71, 4151-4158. 